\title{
Mucispirillum schaedleri gen. nov., sp. nov., a spiral-shaped bacterium colonizing the mucus layer of the gastrointestinal tract of laboratory rodents
}

Correspondence
Jani L. O'Rourke
J.orourke@unsw.edu.au

\section{INTRODUCTION}

The layer of mucus that lines the mammalian gastrointestinal tract (GT) represents a complex ecological niche (Lee, 1980). We have previously hypothesized that bacteria capable of colonizing this site possess specialized characteristics, such as spiral morphology and motility, which give them a selective advantage over other bacterial types in viscous environments and that spiral bacteria have coevolved with their mammalian hosts (Lee, 1985). For example, the mucus lining of the GT of rodents harbours

Published online ahead of print on 4 January 2005 as DOI 10.1099/ ijs.0.63472-0.

Abbreviations: GT, gastrointestinal tract.

The GenBank/EMBL/DDBJ accession numbers for the 16S rRNA gene sequences of nine Mucispirillum schaedleri isolates are AF059186-AF059190 and AY387668-AY387671.

A dendrogram based on whole-cell protein profiles of ten Mucispirillum schaedleri isolates is available as supplementary material in IJSEM Online. large and often diverse populations of spiral bacteria, many of which have been found to be members of the genera Helicobacter and Campylobacter (Davis et al., 1972; Erlandsen \& Chase, 1972; Gordon \& Dubos, 1970; Lee et al., 1968; Phillips et al., 1978; Savage \& Blumershine, 1974).

Recently, a major emphasis of research into GT disease has focused on the role such bacteria, specifically the spiralshaped Helicobacter species, play in the disease processes. In addition to Helicobacter pylori being shown to be a causative agent in gastric disease, there is now accumulating evidence that many other Helicobacter species may be implicated in other gastrointestinal and hepatobiliary diseases, including enteritis, inflammatory bowel disease (IBD), typhlitis, hepatitis and hepatic neoplasia (Fox, 2002; O’Rourke et al., 2001; Schauer, 2001). GT research relies on the mouse as an important animal model for studies on pathogenicity and underpins much of the current research on anti-Helicobacter vaccine development. However, our knowledge of the identity of the many spiral-shaped bacteria that are capable 
of colonizing the mammalian GT is limited and should not be restricted to Helicobacter species. Therefore, it has become a priority to determine the identity of spiral bacteria naturally occurring in laboratory rodents. Although many Helicobacter species have been identified in laboratory mice and rats (Fox et al., 1994, 1995; Lee et al., 1992; Mendes et al., 1996; Robertson et al., 2001; Schauer et al., 1993; Shen et al., 1997), it is becoming increasingly obvious that bacteria belonging to other, possibly unknown, genera are also capable of colonizing the mammalian GT. Such findings would have important implications on how the many models of GT disease are undertaken and interpreted.

During a survey examining spiral bacteria that naturally infect mice obtained from four animal facilities in Sydney, Australia, we cultured a large number of anaerobic spiral bacteria that did not belong to either the genus Helicobacter or the genus Campylobacter. This report presents the taxonomic characterization of these non-helicobacter isolates, including $16 \mathrm{~S}$ rRNA gene sequence, whole-cell protein, biochemical and morphological analyses. Genotypic studies indicated that these isolates fell within the phylum Deferribacteres, which has no close phylogenetic relationship to the genus Helicobacter or to the class Proteobacteria. A specific PCR targeting a region of the $16 \mathrm{~S}$ rRNA gene was developed to define and identify this novel bacterial group. Based on these results a new genus and species, Mucispirillum schaedleri gen. nov., sp. nov., is proposed in honour of Russell Schaedler, one of the early pioneers of the study of the bacteria of the intestinal tract of mammals and the first to isolate a member of this genus (ASF 457) as part of the altered Schaedler flora (Dubos et al., 1965; Savage et al., 1968; Schaedler et al., 1965; Dewhirst et al., 1999).

\section{METHODS}

Bacterial isolation and cultivation. Conventional or Specific Pathogen Free, Quackenbush/Swiss mice $(n=23)$ were obtained from four separate animal facilities in Sydney, Australia. Routine screening for spiral bacteria was performed by culturing intestinal mucus scrapings and homogenized liver samples, as described by Robertson et al. (2001). Briefly, mouse intestinal mucus scrapings or homogenized livers were inoculated directly onto horse blood agar (HBA) and Campylobacter selective agar (CSA). Alternatively, the specimens were first inoculated onto $0.65 \mu \mathrm{m}$ filters (Millipore) on the agar surface of plates and placed in a $37^{\circ} \mathrm{C}$ incubator $\left(10 \% \mathrm{CO}_{2}\right.$ and $95 \%$ humidity) for $2 \mathrm{~h}$. The filters were then removed and discarded. All plates were incubated, lids uppermost, in an anaerobic jar (HP 11; Oxoid) with a microaerobic gas-generating kit (BR 56; Oxoid) or with an anaerobic gas-generating kit (BR 38; Oxoid) at $37^{\circ} \mathrm{C}$ for $72-96 \mathrm{~h}$. After incubation, the plates were examined for growth of spiral bacteria using phase-contrast microscopy. Subcultures were carried out until pure cultures were obtained.

Electron microscopy. Fresh bacterial cultures were fixed in $1 \%$ glutaraldehyde for $1 \mathrm{~min}$, negatively stained with phosphotungstic acid $(1 \%)$ and viewed with a Hitachi H7000 transmission electron microscope.

DNA extraction, 16S rRNA gene amplification and sequencing. DNA was extracted from a loopful of cells using a modification of the bacterial lysis method of Tillett and Neilan (Robertson et al., 2001; Tillett \& Neilan, 2000). PCR amplification and sequencing of the 16S rRNA gene were performed as described by Robertson et al. (2001). In all cases, both strands of DNA were sequenced with contiguous overlaps.

Phylogenetic inferences. Sequences were aligned using the multiple sequence alignment tool in the CLUSTAL X package (Thompson et al., 1997). Aligned sequences were corrected manually and nucleotide positions that contained ambiguities were removed from further analysis. Genetic distances, corrected for multiple base changes by the method of Jukes \& Cantor (1969), were calculated using the DNADIST program in the PHYLIP package, version 3.57c (Felsenstein, 1989). The phylogenetic tree was reconstructed using the neighbourjoining method of Saitou \& Nei (1987) and the tree plotted using NJPLOT in the CLUSTAL X package. Bootstrap analysis of 100 resamplings of the dataset, created using SEQBOOT, were determined using DNADIST and CONSENSE, also from the PHYLIP package (Felsenstein, 1985).

Phenotypic characterization. Five strains were examined using 65 of the tests included in an extensive identification scheme for Campylobacter, Helicobacter and related bacteria as described by On et al. (1996), except that strains were cultured under anaerobic conditions on $\mathrm{BHI}$ agar supplemented with $5 \%$ blood prior to testing. Additional enzyme activities were examined in strain ASF 457 by use of a commercial identification kit (API 32E; bioMérieux). These tests were performed using the manufacturer's guidelines, except that the assays were performed under anaerobic conditions.

SDS-PAGE of whole-cell proteins. Whole-cell protein extracts were prepared and SDS-PAGE performed as described by Pot et al. (1994). The densitometric analysis, normalization and interpolation of the protein profiles, and numerical analysis were performed using the GELCOMPAR software package version 4.2 (Applied Maths), and the profiles were recorded and stored on a PC. The similarity between all pairs of traces was expressed by the Pearson product moment correlation coefficient and is presented as percentages of similarity.

\section{RESULTS AND DISCUSSION}

\section{Isolation, growth characteristics and ultrastructure}

In this study we present the isolation and classification of a group of anaerobic, spiral bacteria cultured from the intestines and livers of laboratory rodents and propose the construction of a new genus and species to accommodate them, Mucispirillum schaedleri. They constituted $27 \cdot 3 \%$ $(30 / 110)$ of the spiral-shaped bacteria isolated in a study of such bacteria in mice. These isolates were found in 13/17 mice originating from three of the animal houses examined in this study, including the Microbiology animal facility at the University of New South Wales (UNSW). The bacteria were most commonly cultivated from caecal samples (14/ 30 ) but they could also be found in ileal, colonic and liver tissue samples $(5 / 30,10 / 30$ and $1 / 30$, respectively). Three additional isolates from our collection of spiral bacteria also fitted this profile. These isolates had been cultured previously from Quackenbush Swiss mice in 1995 and a Wistar rat in 1978 from animals also housed at the Microbiology animal facility, UNSW. Although most of the isolates were cultivated from the mucus layer covering the intestinal tract of the rodents, two of the isolates 
originated from liver samples. This raises the possibility that in certain animals, especially older animals, these bacteria are capable of translocating from the intestinal tract to the hepatobilary system. A similar occurrence has been seen with several Helicobacter species (Fox et al., 1994, 1995; Stanley et al., 1994).

When observed in wet mounts under phase-contrast microscopy these bacteria had a thin, tight spiral morphology. They were Gram-negative and not capable of growth under microaerobic conditions. Electron microscopic examination of a number of isolates revealed that they possessed single, bipolar, unsheathed flagella (Fig. 1).

\section{$16 S$ rRNA gene sequence analysis}

The 16S rRNA gene sequence was determined for nine isolates. All nine sequences had between 96 and $100 \%$ sequence similarity with one another. Sequences obtained from four isolates (HRI I01, HRI I10, HRI I12 and HRI I1 $7^{\mathrm{T}}$ ) had $100 \%$ sequence similarity with each other, while a further three isolates (UNSW I28, UNSW I26 and ABHU I23) also shared $100 \%$ sequence similarity with each other. There were four nucleotide mismatches between these two groups. The remaining two isolates, UNSW I29 and UNSW I30, were slightly less closely related $(96 \cdot 6-97 \cdot 1 \%)$ to the main group. Phylogenetically similar bacteria were also found to have been isolated from a rodent and a Colobus monkey in the USA (strains ASF 457 and Lincoln Park 3, respectively) (Dewhirst et al., 1999; Sarma-Rupavtarm et al., 2004). The 16S rRNA gene sequence of strain ASF 457 was found to have $100 \%$ similarity with four strains isolated in this study, including the nominated type strain, HRI $117^{\mathrm{T}}$. A phylogenetic tree was reconstructed from a multiple sequence alignment (1317 nt in length) of 16 16S rRNA gene sequences (Fig. 2). These included representatives of the four different sequences determined in this study (HRI I $7^{\mathrm{T}}$, UNSW I26, UNSW I29 and UNSW I30) and representatives from the Deferribacteraceae that were the most closely related taxa returned in searches of sequences available in the GenBank database.

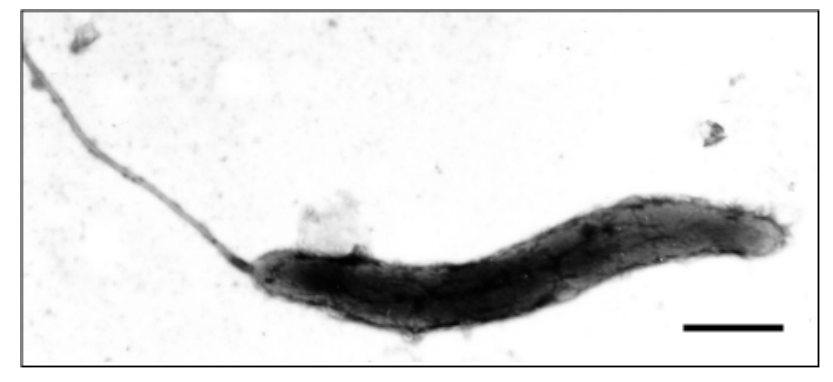

Fig. 1. Transmission electron micrograph of Mucispirillum schaedleri sp. nov., a spiral-shaped bacterium with bipolar flagella measuring $4 \mu \mathrm{m} \times 0.4 \mu \mathrm{m}$ in size. Negative stain. Bar, $0.66 \mu \mathrm{m}$.
The phylum Deferribacteres is a relatively recently described lineage within the bacterial domain (Huber \& Stetter, 2001). Four genera, each containing small numbers of species, are described in the Deferribacteraceae, Flexistipes (Fiala et al., 1990), Geovibrio (Caccavo et al., 1996), Deferribacter (Greene et al., 1997) and Denitrovibrio (Myhr \& Torsvik, 2000). The level of sequence similarity between our sequences described above and other bacteria in this group $(80-85 \%)$ did not support a generic classification.

\section{Specific PCR development}

Based on the comparison of 16S rRNA gene sequences obtained here with those from other bacterial groups, oligonucleotides were designed for use in a PCR to identify other bacterial isolates as members of this previously unrecognized bacterial group. Candidate primers were identified at nucleotide positions 137-158 and 1115-1134 (Escherichia coli numbering) and were designated MsF158 (5'-TTTTAGACTGGAACAACTTACC-3') and MsR1115 (5'-CTATTTCCAGTTGCTAACGG-3'), respectively. The $16 \mathrm{~S}$ rRNA gene sequence from the Colobus monkey isolate, Lincoln Park 3, did not show similarity to either MsF158 (six mismatches) or MsR1115 (two mismatches), nor did the other sequences representing members of the phylum Deferribacteres. PCRs were prepared as described above and the specific amplification of DNA from the nine sequenced isolates was achieved using the following thermocycling profile. An initial denaturation at $94^{\circ} \mathrm{C}$ for 3 min was followed by 30 cycles of $94^{\circ} \mathrm{C}$ for $45 \mathrm{~s}, 55^{\circ} \mathrm{C}$ for $45 \mathrm{~s}$ and $72{ }^{\circ} \mathrm{C}$ for $1 \mathrm{~min}$. Amplification was completed by a single extension step at $72^{\circ} \mathrm{C}$ for $10 \mathrm{~min}$. A range of DNA from other bacterial types served as negative controls. Using this PCR, all 33 isolates cultured on CSA under anaerobic conditions gave a positive result (data not shown).

\section{Physiological and biochemical characterization}

Five strains (ABHU I23, HRI I12, HRI I17 ${ }^{\mathrm{T}}$, UNSW I26 and ASF 457) were further characterized with a comprehensive range of phenotypic tests. They were shown to produce oxidase and catalase. Strain ASF 457 grew only on BHI medium and not on the standard $5 \%$ blood agar used as the base medium for growth tests. Similarly, only ASF 457 proved unable to grow on $5 \%$ blood agar medium that contained cephalothin $\left(32 \mathrm{mg} \mathrm{l}^{-1}\right)$, carbenicillin (32 $\mathrm{mg} \mathrm{l}^{-1}$ ) or cefoperazone (64 $\mathrm{mg} \mathrm{l}^{-1}$ ); the remaining four strains proved resistant to these antibiotics under the conditions examined. However, no positive results were observed among any of the five strains in the remainder of the conventional tests used to characterize them (see species description below for details). By use of the API 32E kit, acidification of the substrates L-arabitol, galacturonate and 5-ketoglutonate was consistently detected in strain ASF 457.

\section{SDS-PAGE of whole-cell proteins}

Whole-cell protein extracts from ten isolates (UNSW I24, UNSW I25, UNSW I26, UNSW I29, UNSW I30, HRI I01, 


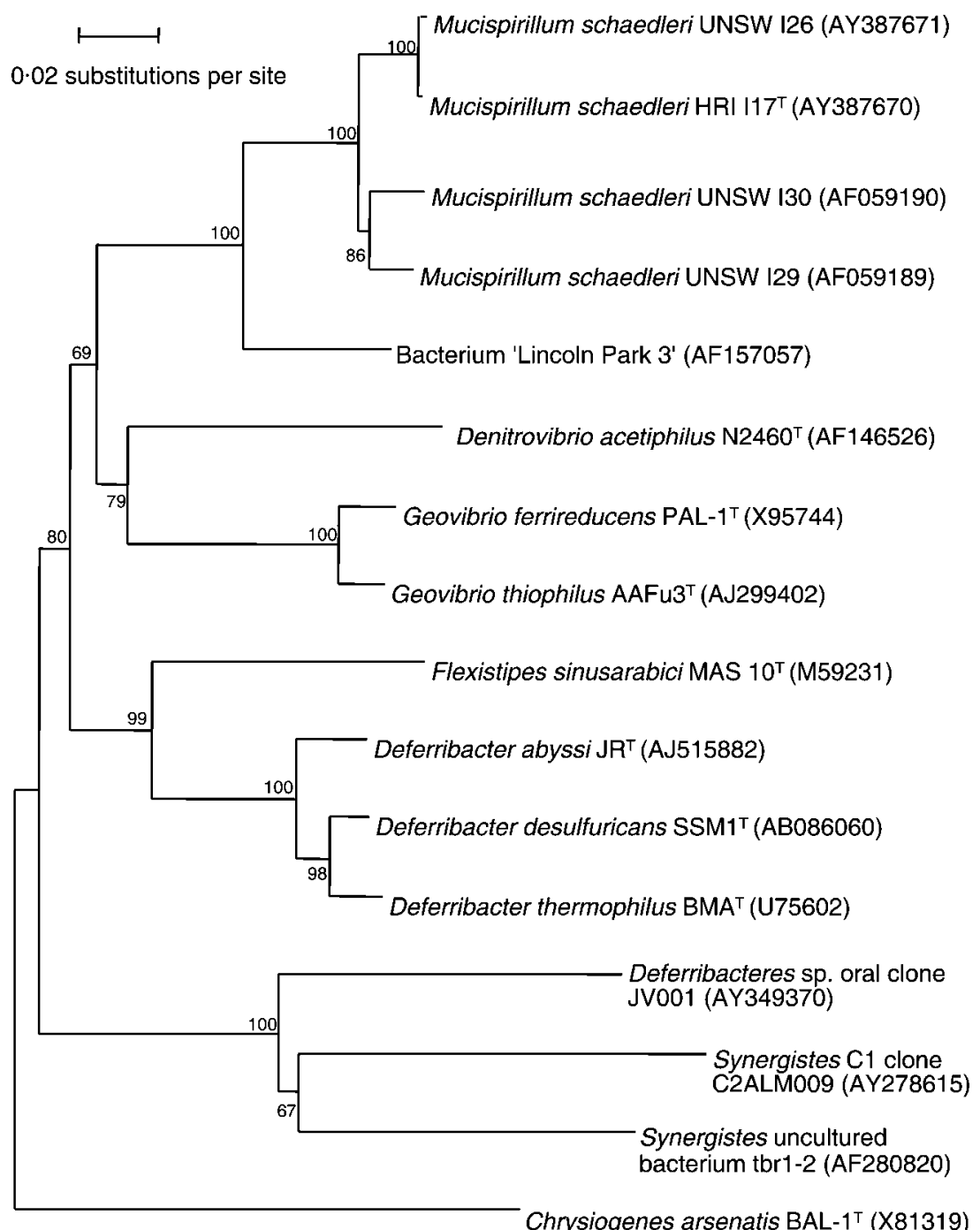

Fig. 2. Phylogenetic tree showing the position of Mucispirillum schaedleri sp. nov. based on analysis of near-complete $16 \mathrm{~S}$ rRNA gene sequences derived from members of the Deferribacteres with Chrysiogenes arsenatis as the outgroup. Bar, 0.02 substitutions per site. Bootstrap values are indicated at the nodes.
HRI I10, HRI I12, HRI $I 17^{\mathrm{T}}$ and ABHU I23) were subjected to SDS-PAGE. All ten isolates had very similar cellular protein profiles with similarity levels above $92.6 \%$ (see Supplementary Fig. A in IJSEM Online). The high degree of whole-cell protein similarity strongly suggests that all ten isolates examined represent a single species (Pot et al., 1994). This is further endorsed by the extremely high level of $16 \mathrm{~S}$ rRNA gene sequence similarity $(>99 \cdot 7 \%$ ) among six of these isolates. The two isolates with slightly diverging $16 \mathrm{~S}$ rRNA gene sequences (UNSW I29 and UNSW I30, $\sim 96-97 \%$ similarity to the other isolates examined) cluster among the other isolates (Supplementary Fig. A), demonstrating that the observed differences in 16S rRNA gene sequences reflect intraspecies diversity. Although no DNA-DNA hybridization experiments were performed, the unique phylogenetic position (Fig. 2) and the high degree of consensus among the phenotypic and genotypic results indicate that it is appropriate to classify all ten murine isolates into a single novel species in a novel genus (Ursing et al., 1995).
Prior to this study the majority of spiral-shaped bacteria identified in the mammalian GT were found to belong to the phylum Proteobacteria [genera Helicobacter and Campylobacter, of the $\varepsilon$-Proteobacteria (Murray et al., 1990; Vandamme et al., 1991), and the genus Anaerobiospirillum of the $\gamma$-Proteobacteria (On, 2001)]. In contrast, the phylogenetic position of Mucispirillum, the mucosa-associated spiral-shaped bacterium described in this report, is within the phylum Deferribacteres, a completely distinct lineage within the domain Bacteria. Members of the family Deferribacteraceae have been isolated from a range of diverse water-based environmental samples. These bacteria, including Mucispirillum, are all anaerobic but share few other phenotypic characteristics except for being curved rods, vibroid or, in the case of Mucispirillum isolates, spiralshaped. The majority are motile and they also include thermophilic as well as mesophilic organisms.

A recent study by Paster et al. (2001) also raises the possibility that a genetically similar group of organisms may 
be able to colonize the oral cavity of humans, a niche known to be colonized by other spiral-shaped bacteria. In this study bacterial diversity in subgingival plaque was examined by analysis of a $16 \mathrm{~S}$ rRNA gene sequence clonal library derived from healthy individuals and those showing signs of periodontal disease. Eighty-six of the 2522 clones analysed fell within the phylum Deferribacteres and formed eight separate phylotypes (clusters of clone sequences that differed from known species by approximately $2 \%$ and were at least $99 \%$ similar to members of their cluster).

In addition to the 30 Mucispirillum isolates cultured for this study, the fact that single isolates had been cultured previously from rodents on several occasions both in Australia and in the United States over many years indicates that this group of organisms is not geographically restricted. The isolation of a phylogenetically closely related bacterium from a Colobus monkey is interesting and suggests that there may exist additional species within this genus colonizing the intestinal tract of a variety of mammals in a similar way as has been shown for the genus Helicobacter. The development of a specific PCR, as described here, will allow for preliminary screening studies to determine the distribution of these organisms in the GT and possibly the oral cavity of humans and a range of mammalian species. The significance of the genetic relatedness of Mucispirillum to other members of the family Deferribacteraceae, a range of unusual environmental isolates, is at present unclear. However, the selective pressure of viscous environments such as mucus and oil reservoirs has resulted in a common phenotypic trait, curved to spiral-shaped motile organisms.

\section{Description of Mucispirillum gen. nov.}

Mucispirillum (Mu.ci.spi'ril.lum. L. n. mucus mucus; N.L. dim. neut. n. spirillum a small spiral; N.L. neut. n. mucispirillum a small spiral rod of the mucus).

Gram-negative curved to spiral rods with single, unsheathed, bipolar flagella. No spores formed. Anaerobic; no growth obtained under microaerobic or aerobic conditions. Phylogenetically the genus belongs to the phylum Deferribacteres.

The type species is Mucispirillum schaedleri.

\section{Description of Mucispirillum schaedleri sp. nov.}

Mucispirillum schaedleri (schaed'ler.i. N.L. gen. n. schaedleri of Schaedler, in honour of Russell Schaedler, one of the pioneers in the study of the bacteria of the intestinal tract of mammals).

Gram-negative curved to spiral rods $(3-4 \mu \mathrm{m} \times 0 \cdot 4 \mu \mathrm{m})$ with single, unsheathed, bipolar flagella. No spores formed. Anaerobic growth at $37^{\circ} \mathrm{C}$; no growth obtained under microaerobic or aerobic conditions or at $42{ }^{\circ} \mathrm{C}$. Does not readily form single colonies, and requires 3-5 days for growth on $5 \%$ HBA. Non-haemolytic. Bacterial growth is not pigmented and pitting of the agar medium is not seen.
Oxidase- and catalase-positive. Does not reduce nitrate, selenite or triphenyl-tetrazolium chloride. Hydrogen sulfide production in triple-sugar iron agar is not seen. Most (80\%) strains grow on $5 \%$ blood agar medium containing $32 \mathrm{mg}$ cephalothin $\mathrm{l}^{-1}, 32 \mathrm{mg}$ carbenicillin $\mathrm{l}^{-1}$ or $64 \mathrm{mg}$ cefoperazone $1^{-1}$. Strains do not grow on tyrosine, casein, lecithin or minimal agar medium, or on media containing $32 \mathrm{mg}$ nalidixic acid $1^{-1}, 100 \mathrm{IU}$ 5-fluorouracil, $0 \cdot 05 \%$ sodium fluoride, $0.032 \%$ methyl orange, $0.005 \%$ basic fuchsin, $1.0 \%$ glycine, $2-4 \% \mathrm{NaCl}, 0 \cdot 1 \%$ potassium permanganate, $0.0001 \%$ sodium arsenite, $0 \cdot 02-0 \cdot 05 \%$ safranin, $0 \cdot 0005 \%$ crystal violet, $0 \cdot 01 \%$ janus green or $0 \cdot 02 \%$ pyronin. Isolated from the gastrointestinal mucus of rodents.

The type strain, HRI $I 17^{\mathrm{T}}\left(=\mathrm{ATCC}\right.$ BAA $-1009^{\mathrm{T}}=\mathrm{ACM}$ $5223^{\mathrm{T}}$ ), was isolated from mouse caecal mucus.

\section{ACKNOWLEDGEMENTS}

Automated sequencing was performed at the UNSW Automated DNA Analysis Facility.

\section{REFERENCES}

Caccavo, F., Jr, Coates, J. D., Rossello-Mora, R. A., Ludwig, W., Schleifer, K. H., Lovley, D. R. \& McInerney, M. J. (1996). Geovibrio ferrireducens, a phylogenetically distinct dissimilatory $\mathrm{Fe}(\mathrm{III})$ reducing bacterium. Arch Microbiol 165, 370-376.

Davis, C. P., Mulcahy, D., Takeuchi, A. \& Savage, D. C. (1972). Location and description of spiral-shaped microorganisms in the normal rat cecum. Infect Immun 6, 184-192.

Dewhirst, F. E., Chien, C. C., Paster, B. J., Ericson, R. L., Orcutt, R. P., Schauer, D. B. \& Fox, J. G. (1999). Phylogeny of the defined murine microbiota: altered Schaedler flora. Appl Environ Microbiol 65, 32873292.

Dubos, R., Schaedler, R. W., Costello, R. \& Hoet, P. (1965). Indigenous, normal, and autochthonous flora of the gastrointestinal tract. $J$ Exp Med 122, 67-76.

Erlandsen, S. L. \& Chase, D. G. (1972). Paneth cell function: phagocytosis and intracellular digestion of intestinal microorganisms. II. Spiral microorganisms. J Ultrastruct Res 41, 319-333.

Felsenstein, J. (1985). Confidence limits on phylogenetics: an approach using the bootstrap. Evolution 39, 783-791.

Felsenstein, J. (1989). PHYLIP - phylogeny interface package (version 3.2). Cladistics 5, 164-166.

Fiala, G., Woese, C. R., Langworthy, T. A. \& Stetter, K. O. (1990). Flexistipes sinusarabici, a novel genus and species of eubacteria occurring in the Atlantis II deep brines of the Red Sea. Arch Microbiol 154, 120-126.

Fox, J. G. (2002). The non-H. pylori helicobacters: their expanding role in gastrointestinal and systemic diseases. Gut 50, 273-283.

Fox, J. G., Dewhirst, F. E., Tully, J. G., Paster, B. J., Yan, L., Taylor, N. S., Collins, M. J., Jr, Gorelick, P. L. \& Ward, J. M. (1994). Helicobacter hepaticus sp. nov., a microaerophilic bacterium isolated from livers and intestinal mucosal scrapings from mice. J Clin Microbiol 32, 1238-1245.

Fox, J. G., Yan, L. L., Dewhirst, F. E., Paster, B. J., Shames, B., Murphy, J. C., Hayward, A., Belcher, J. C. \& Mendes, E. N. (1995). 
Helicobacter bilis sp nov, a novel Helicobacter species isolated from bile, livers, and intestines of aged, inbred mice. J Clin Microbiol 33, 445-454.

Gordon, J. H. \& Dubos, R. (1970). The anaerobic bacterial flora of the mouse cecum. J Exp Med 132, 251-260.

Greene, A. C., Patel, B. K. \& Sheehy, A. J. (1997). Deferribacter thermophilus gen. nov., sp. nov., a novel thermophilic manganeseand iron-reducing bacterium isolated from a petroleum reservoir. Int $J$ Syst Bacteriol 47, 505-509.

Huber, H. \& Stetter, K. O. (2001). Class I. Deferribacteres class. nov. In Bergey's Manual of Systematic Bacteriology, 2nd edn, vol. 1, p. 465. Edited by D. R. Boone, R. W. Castenholz \& G. M. Garrity. New York: Springer.

Jukes, T. H. \& Cantor, C. R. (1969). Evolution of protein molecules. In Mammalian Protein Metabolism, vol. 3, pp. 21-132. Edited by H. N. Munro. New York: Academic Press.

Lee, A. (1980). Normal flora of animal intestinal surfaces. In Adsorption of Microorganisms to Surfaces, pp. 145-173. Edited by G. Bitton \& K. C. Marshall. New York: Wiley.

Lee, A. (1985). Neglected niches: the microbial ecology of the gastrointestinal tract. In Advances in Microbial Ecology, pp. 115-162. Edited by K. C. Marshall. New York: Plenum.

Lee, A., Gordon, J. \& Dubos, R. (1968). Enumeration of the oxygen sensitive bacteria usually present in the intestine of healthy mice. Nature 220, 1137-1139.

Lee, A., Phillips, M. W., O’Rourke, J. L. \& 8 other authors (1992). Helicobacter muridarum sp. nov., a microaerophilic helical bacterium with a novel ultrastructure isolated from the intestinal mucosa of rodents. Int J Syst Bacteriol 42, 27-36.

Mendes, E. N., Queiroz, D. M. M., Dewhirst, F. E., Paster, B. J., Moura, S. B. \& Fox, J. G. (1996). Helicobacter trogontum sp. nov., isolated from the rat intestine. Int J Syst Bacteriol 46, 916-921.

Murray, R. G. E., Brenner, D. J., Colwell, R. R., De Vos, P., Goodfellow, M., Grimont, P. A. D., Pfennig, N., Stackebrandt, E. \& Zavarzin, G. A. (1990). Report of the ad hoc committee on approaches to taxonomy within the Proteobacteria. Int $J$ Syst Bacteriol 40, 213-215.

Myhr, S. \& Torsvik, T. (2000). Denitrovibrio acetiphilus, a novel genus and species of dissimilatory nitrate-reducing bacterium isolated from an oil-reservior model column. Int J Syst Evol Microbiol 50, 16111619.

On, S. L. W. (2001). Taxonomy of Campylobacter, Arcobacter, Helicobacter and related bacteria: current status, future prospects and immediate concerns. Symp Ser Soc Appl Microbiol 1S-15S.

On, S. L. W., Holmes, B. \& Sackin, M. J. (1996). A probability matrix for the identification of campylobacters, helicobacters and allied taxa. J Appl Bacteriol 81, 425-432.

O’Rourke, J. L., Grehan, M. \& Lee, A. (2001). Non-pylori helicobacter species in humans. Gut 49, 601-606.

Paster, B. J., Boches, S. K., Galvin, J. L., Ericson, R. E., Lau, C. N., Levanos, V. A., Sahasrabudhe, A. \& Dewhirst, F. E. (2001). Bacterial diversity in human subgingival plaque. J Bacteriol 183, 3770-3783.

Phillips, M., Lee, A. \& Leach, W. D. (1978). The mucosa-associated microflora of the rat intestine: a study of normal distribution and magnesium sulphate induced diarrhoea. Aust J Exp Biol Med Sci 56, 649-662.
Pot, B., Vandamme, P. \& Kersters, K. (1994). Analysis of electrophoretic whole-organism protein fingerprints. In Modern Microbial Methods. Chemical Methods in Prokaryotic Systematics, pp. 493-521. Edited by M. Goodfellow \& A. G. O’Donnell. Chichester: Wiley.

Robertson, B. R., O'Rourke, J. L., Vandamme, P., On, S. L. W. \& Lee, A. (2001). Helicobacter ganmani sp. nov., a urease-negative anaerobe isolated from the intestines of laboratory mice. Int J Syst Evol Microbiol 51, 1881-1889.

Saitou, N. \& Nei, M. (1987). The neighbor-joining method: a new method for reconstructing phylogenetic trees. Mol Biol Evol 4, 406425.

Sarma-Rupavtarm, R. B., Ge, Z. M., Schauer, D. B., Fox, J. G. \& Polz, M. F. (2004). Spatial distribution and stability of the eight microbial species of the altered Schaedler flora in the mouse gastrointestinal tract. Appl Environ Microbiol 70, 2791-2800.

Savage, D. C. \& Blumershine, R. V. H. (1974). Surface-surface associations in microbial communities populating epithelial habitats in the murine gastrointestinal ecosystem: scanning electron microscopy. Infect Immun 10, 240-250.

Savage, D. C., Dubos, R. \& Schaedler, R. W. (1968). The gastrointestinal epithelium and its autochthonous bacterial flora. $J$ Exp Med 127, 67-76.

Schaedler, R. W., Dubos, R. \& Costello, R. (1965). The development of the bacterial flora in the gastrointestinal tract of mice. J Exp Med 122, 59-66.

Schauer, D. B. (2001). Enterohepatic Helicobacter species. In Helicobacter pylori: Physiology and Genetics, pp. 533-548. Edited by H. L. T. Mobley, G. L. Mendz \& S. L. Hazell. Washington, DC: American Society for Microbiology.

Schauer, D. B., Ghori, N. \& Falkow, S. (1993). Isolation and characterization of "Flexispira rappini" from laboratory mice. J Clin Microbiol 31, 2709-2714.

Shen, Z., Fox, J. G., Dewhirst, F. E., Paster, B. J., Foltz, C. J., Yan, L., Shames, B. \& Perry, L. (1997). Helicobacter rodentium sp. nov., a urease-negative Helicobacter species isolated from laboratory mice. Int J Syst Bacteriol 47, 627-634.

Stanley, J., Linton, D., Burnens, A. P., Dewhirst, F. E., On, S. L. W., Porter, A., Owen, R. J. \& Costas, M. (1994). Helicobacter pullorum sp. nov. - genotype and phenotype of a new species isolated from poultry and from human patients with gastroenteritis. Microbiology 140, 3441-3449.

Thompson, J. D., Gibson, T. J., Plewniak, F., Jeanmougin, F. \& Higgins, D. G. (1997). The CLUSTAL_X Windows interface: flexible strategies for multiple sequence alignments aided by quality analysis tools. Nucleic Acids Res 25, 4876-4882.

Tillett, D. \& Neilan, B. A. (2000). Rapid nucleic acid isolation from cultured and environmental cyanobacteria: novel techniques based on xanthogenate. J Phycol 36, 251-258.

Ursing, J. B., Rosselló-Mora, R. A., Garcia-Valdés, E. \& Lalucat, J. (1995). Taxonomic note: a pragmatic approach to the nomenclature of phenotypically similar genomic groups. Int J Syst Bacteriol 45, 604. Vandamme, P., Falsen, E., Rossau, R., Hoste, B., Segers, P., Tytgat, R. \& De Ley, J. (1991). Revision of Campylobacter, Helicobacter, and Wolinella taxonomy: emendation of generic descriptions and proposal of Arcobacter gen. nov. Int J Syst Bacteriol 41, 88-103. 